\title{
Identification of Problem in Lorry Production Using FMEA (Failure Mode Effect and Analysis)
}

\author{
Ikhsan Siregar ST, M.Eng
}

\begin{abstract}
Manufacturing company is producing lorries in large amoung thus the company is demanded to mantain and increase the consistency of the company in quality and quantity of each product unit in production process. This is done to ensure the survivability of the company in competition with the competitors. After a long operational duration, a product defect is detected due to production process, the research thus aimed to supervise and identify the source of the defect. Failure Mode and Effect Analysis (FMEA) is a method that can be used to identify the cause of defect in a production process. Thus using this method, an analysis of related factor in production process can be conducted. The result of the research showed that error was mostly happened in iron plate cutting process due to inexperienced operator, where the value of Risk Priority Number (RPN) was 21 and other process was having the value of 245 . As a conclusion, the greatest defect in production process was caused by the operator.
\end{abstract}

Keywords - Product defect, Failure Mode and Effect Analysis (FMEA),Operator, Quality, Risk Priority Number (RPN)

\section{Introduction}

In modern industry these days, industry with the same type or the same product is emerging everywhere increasingly. In fulfilling the consumer demand on the product, each industry will try its best on inovating in developing their product in accordance to consumers demands. This has been initiating tight competition between companies. Regarding this facts, every company has to have an objective to gain competitive advantage in cost or even in quality. The competitive advantage is signed by the low cost and high working efficiency, while operations were consumer oriented in terms of quality. The company to be observed is having business in lorry production, agricultural equipment and the repairment of agricultural equipment. At the moment, defects and failures were happening frequently and left undetected by the company. FMEA method is a method that can be used to identify the cause of the failures. In FMEA method, there is two mindset that being the base of analyisi, namely Failure Modes which asessed as an error or obstruction in form of process, design or physical matter mainly those who have effects on consumer potentially or actually. Analysis Effect is the part that referred to an analysis on the consequences of failures.

Previous researches regarding FMEA is numerous, some of them is the repairment and creation of innovation in project actuation and management (Bahrami, 2012). Other research mentioned that FMEA can identify the effect of failure mode application which later being useful for analysis (Trafialek, 2014). Other reasearches that has resemblance of type suppports the identification and management of vehicle components flexibly (Renu, 2016). Where in other research was using FMEA to predict failure risk in a construction process (Meraj, 2015). FMEA method is used mainly in researches that identifying risk of failures in many fields, commonly on manufacture industries, such as the analysis in electricity generator in Iran (Feili, 2013). Also some other researches in manufacture such as risk analysis in feed production (Wessiani, 2015). This kind of research was also been done to asses failure risk on offshore industries (Yang, 2014). The method has never been used to identify failure on manufacture company that produces lorries and agricultural equipments, where operator is having an important role in product manufacturing. The research attempted to obeserve deeply the problem in the industry.

\section{Research Methodology}

FMEA is a systematic process to identify potential of failures that would emerge in a process with objectives to eliminate or minimize the risk of production failure. The use of FMEA was introduced for the first time on 1920. The first documentation was done since 1960 by National Aeronautics Space Agency (NASA) which was originated to improve reliabilities of military equipments (Besterfield, 1994)

The main objective of FMEA is to find and repair the main problem that happened in each stages of design and production process to prevent unqualified product to reach the consumers, which will endanger the reputation of the company.

\section{A. Determination of Effect of Potential Failure}

The potential failure effect is an effect that caused by a failure to a consumer. The consumer in FMEA is consisted by :

1. Downstream user / next user, which is the next process in a process flow.

2. Ultimate consumer, which is the final consumer.

3. Vehicle operation, which is a process of vehicle operation.

4. Operator safety, which is the safety of operator, those in producer factory or in assembly factory.

5. Compliance with government regulation, which is the compliance with governmental rules, such as allowed emission.

6. Machine / equipment, which is the effect on machine and other equipment, such as wear and tear or easy to break.

If the effect is in the form of breaking of govermental rules, it is suggested that identity / reference of the rules to be added to make further analysis easier.

Ikhsan Siregar

Departement of Industrial Engineering, University of Sumatera Utara Indonesia 


\section{B. Determination of Severity value (S)}

Severity is a rank that shows how serious is the effect of a failure mode. Severity is a number between 1 to 10 , where 1 shows lowest seriousness (low risk) and 10 shows highest level of seriousness (high risk).

\section{Identification of Potential Failure Cause}

The potential failure cause is a potential cause that can result in failure. The cause of failure can be defined with correctable or controllable jargon. Namely :

1. Excessive torque pressure

2. Worn/broken equipment

3. Insufficient welding current

4. Incorrect measurement equipment

The potential cause will display only spesific error, for example, the operator installed the machine wrongly. Ambiguous jargon (such as operator error, malfunctioned machine) is advised to be avoided, for it will causing the determination of recommended action becomes difficult. It is advisable that the jargon would be replaced as follows, "operator error" to "error in work diagram reading", "malfunctioned" to "the machine fails to produce heat more than $1500^{\circ} \mathrm{C}$ ". Potential cause can be found by using brainstorming method and fishbone diagram while considering $4 \mathrm{M}+1 \mathrm{E}$ factors.

\section{Occurence Value (O)}

Occurence is a measure of how often a potential cause to happen. Occurance value is a number between 1 and 10, where 1 shows low occurence or not often and 10 shows high occurence.

Occurence value can be determined by the number of failure or tha value of Ppk (Performance Index) which is a value that is obtained by statistical calculation which shows performace or capability of a process in manufacturing a product that fits the spesification. Occurence value can be lowered by preventing or controlling causes / mechanism through the design of process.

\section{E. Determination of Detection Value}

\section{(D)}

Detection is a rank of how accurate the detection equipment that is used. Detection is a number between 1 and 10 , where 1 shows detection system with high capability or can ensure a mode of failure to be detected, where 10 shows a detection system with low capability where detection system is ineffective or unable to detect at all.

Detection value can be determined using criterias as follows :

1. Error Proofed, which can be a detection equipment that is error-proofing

2. Gauging, which is an inspectoral auxiliary equipment.

3. Manual inspection, which is a manual inspection.

\section{F. Determining RPN (Risk Priority Number) Value}

RPN or Risk Priority Number, is a number that stated a scale of priority in quality risk which is used in guidelines in making planning. RPN is a multiplication of Severity, Occurence and Detection

$$
\mathrm{RPN}=\mathrm{S} \times \mathrm{O} \times \mathrm{D}
$$

RPN is a value between 1 to 1000 , where the higher RPN indicates the process is more risky in making a product with desired spesification.

\section{Results and Discussion}

The collection of data was conducted in Central Workshop of PT Perkebunan Nusantara II which is done in lorry subconstruction. The collection of data that heen done in the research was done by direct observation in each stages of lorry manufacture and interviewing every operator of each process of lorry manufacture. From the result of interview to each operators of each components manufacture of lorries, there were some defect that is frequently happened in the making of lorry components. The defects are as follows :

1. Mistake in the cuttting of front, back left and right wall and also the base part.

2. Non circular form of $\mathrm{L}$ shaped beams in the making of "circle".

3. L shaped beams were torn in the process of bending the internal and external chassis.

4. L shaped beams were folded in the process of bending the internal and external chassis.

\section{A. FMEA of Failure in Cutting}

From the existing failure, it can be observed that emerging effect by the error was the high disposing rate of good quality of iron plate.

\section{B. Determination of Failure Effect Value (Severity, $S$ )}

From the interviews with the company and lorry manufacture operators, thus the Failure Effect Value (S) can be determined from the type of failure. The reason of value determination is as follows :

Iron plate that was wrongly cut will cause an effect of high dispose number of iron plate which actually has good quality, this will be assigned the value of 7 , this is caused by

- A bit disturbance of production line

- Mostly become scrap, where the rest of it can be sorted

- Consumer become dissatisfied 
Proc. of Sixth International Conference On Advances in Mechanical, Aeronautical and Production Techniques - MAPT $2016 .$.

Copyright $@$ Institute of Research Engineers and Doctors. All rights reserved.

ISBN no. 978-1-63248-112-2 doi: 10.15224/ 978-1-63248-112-2-34

\section{Identification of Potential Failure Cause}

By observing the cause and effect diagram, it can be inferred that the main cause of failure for the effect "High dispose of iron plate with good quality" was caused by :

a. Sub optimal cutting process

b. Incorrect Blander machine setting

\section{Determination of Failure Probability (Occurrence, 0 )}

From the interviews result with the company, failure probability value thus can be determined from failure of error in cutting which can be assigned failure probability value as follows :

1. Operator was inobservant in the cutting process thus assigned the value of 6 because the occurence can be found in 6 to 10 occurence. Thus based on the table of occurence value, it can be categorized as mediocre.

2. The incorrect setting of blander machine was assigned the value of 5 because the occurence can be found in 5 to 10 occurence. Thus based on occurence value, it can be categorized as mediocre.

\section{E. Identification of Failure Control Method}

By observing the existing cause of failure thus a control can be done to the cause of failure which can be done by workers or even company to minimize the risk of failure, the control method is as seen on following table.

\begin{tabular}{|c|c|c|c|c|}
\hline $\begin{array}{l}\text { Process } \\
\text { Function }\end{array}$ & $\begin{array}{l}\text { Type of } \\
\text { Process } \\
\text { Failure }\end{array}$ & $\begin{array}{c}\text { Emerged } \\
\text { Effect }\end{array}$ & $\begin{array}{c}\text { The cause of } \\
\text { failure on } \\
\text { process }\end{array}$ & $\begin{array}{l}\text { Control to be } \\
\text { done }\end{array}$ \\
\hline Lorry & $\begin{array}{l}\text { Mistake } \\
\text { in } \\
\text { cutting }\end{array}$ & $\begin{array}{l}\text { High } \\
\text { amount } \\
\text { of } \\
\text { disposed } \\
\text { good } \\
\text { quality } \\
\text { iron } \\
\text { plate }\end{array}$ & $\begin{array}{l}\text { - Inobservant } \\
\text { in cutting } \\
\text { process } \\
\text { - Mistake in } \\
\text { blander } \\
\text { machine } \\
\text { operation }\end{array}$ & 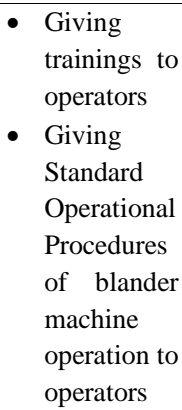 \\
\hline
\end{tabular}

\section{F. Determination of Failure Detection Value (Detection, D)}

From the interviews with the company, the value of Failure Detection (D) of failure in cutting process can be determined. The value is a seen on the table below.

\begin{tabular}{|l|l|l|l|l|l|}
\hline Process & $\begin{array}{l}\text { Type of } \\
\text { Function } \\
\text { Process } \\
\text { Failure }\end{array}$ & $\begin{array}{l}\text { Emerged } \\
\text { Effect }\end{array}$ & $\begin{array}{l}\text { The cause of } \\
\text { failure on } \\
\text { process }\end{array}$ & $\begin{array}{l}\text { Control to } \\
\text { be done }\end{array}$ & D \\
\hline Lorry & $\begin{array}{l}\text { Mistake } \\
\text { in } \\
\text { cutting }\end{array}$ & $\begin{array}{l}\text { High } \\
\text { amount } \\
\text { of } \\
\text { disposed } \\
\text { good } \\
\text { quality } \\
\text { iron plate }\end{array}$ & $\begin{array}{l}\text { Inobservant in } \\
\text { cutting process }\end{array}$ & $\begin{array}{l}\text { Giving } \\
\text { trainings to } \\
\text { operators }\end{array}$ & 5 \\
\cline { 4 - 6 } & $\begin{array}{l}\text { Mistake inder machine } \\
\text { operation }\end{array}$ & $\begin{array}{l}\text { Giving } \\
\text { Standard } \\
\text { Operational } \\
\text { Procedures } \\
\text { of blander } \\
\text { machine } \\
\text { operation } \\
\text { to } \\
\text { operators }\end{array}$ & 3 \\
& & & & & \\
\hline
\end{tabular}

\section{G. Determining The Value of RPN}

From the interviews with the company, the value of Severity (S), Occurence (O) and Detection (D) of every type of failure that occured can be determined. For example, the calculation of RPN is as follows.

Suppose for the effect that is emerged from the high amount of good quality iron plate disposed, which is caused by inobservant operator in cutting process with operator controlled by giving trainings in cutting process.

Failure effect (Severity, S) was given the value of 7

Failure probablity (Occurence, $\mathrm{O}$ ) was given the value of 6

Failure detection (Detection, D) was given the value of 5

Thus $\mathrm{RPN}=\mathrm{S} \times \mathrm{O} \times \mathrm{D}=7 \times 6 \times 5=210$

FMEA table on the process with RPN values is entirely can be seen on following table.

\begin{tabular}{|c|c|l|l|l|l|l|l|l|}
\hline $\begin{array}{c}\text { Process } \\
\text { Func. }\end{array}$ & $\begin{array}{l}\text { Type of } \\
\text { Process } \\
\text { Failure }\end{array}$ & $\begin{array}{l}\text { Emerged } \\
\text { Effect }\end{array}$ & $\mathrm{S}$ & $\begin{array}{l}\text { The cause } \\
\text { of failure }\end{array}$ & $\mathrm{O}$ & $\begin{array}{l}\text { Control } \\
\text { to be } \\
\text { done }\end{array}$ & $\mathrm{D}$ & $\mathrm{RPN}$ \\
\hline Lorry & $\begin{array}{l}\text { Mistake } \\
\text { in cutting }\end{array}$ & $\begin{array}{l}\text { High } \\
\text { amount } \\
\text { of } \\
\text { disposed } \\
\text { good } \\
\text { quality } \\
\text { iron plate }\end{array}$ & 7 & $\begin{array}{l}\text { Inobservant } \\
\text { in cutting } \\
\text { process }\end{array}$ & $\begin{array}{l}\text { Miving } \\
\text { trainings } \\
\text { to } \\
\text { operators }\end{array}$ & 5 & 210 \\
& & $\begin{array}{l}\text { Mistake in } \\
\text { blander } \\
\text { machine } \\
\text { operation }\end{array}$ & 5 & $\begin{array}{l}\text { Giving } \\
\text { Standard } \\
\text { Operatio } \\
\text { nal } \\
\text { Procedur } \\
\text { es } \\
\text { blander } \\
\text { machine } \\
\text { operation } \\
\text { to } \\
\text { operators }\end{array}$ & 3 & 105 \\
\hline
\end{tabular}




\section{H. Failure Mode and Effect Analysis (FMEA) of mistake in circle making}

\begin{tabular}{|c|c|c|c|c|c|c|c|c|}
\hline $\begin{array}{l}\text { Process } \\
\text { Funct. }\end{array}$ & $\begin{array}{l}\text { Type } \\
\text { of } \\
\text { Process } \\
\text { Failure }\end{array}$ & $\begin{array}{c}\text { Emerged } \\
\text { Effect }\end{array}$ & $\mathrm{S}$ & $\begin{array}{c}\text { The cause } \\
\text { of failure } \\
\text { on process }\end{array}$ & $\mathrm{O}$ & $\begin{array}{l}\text { Control to } \\
\text { be done }\end{array}$ & D & RPN \\
\hline \multirow[t]{3}{*}{ Lorry } & \multirow[t]{3}{*}{$\begin{array}{l}\text { The L } \\
\text { shaped } \\
\text { beams } \\
\text { were } \\
\text { torn }\end{array}$} & \multirow{3}{*}{$\begin{array}{l}\text { High } \\
\text { amount } \\
\text { of } \\
\text { disposed } \\
\text { good } \\
\text { quality L } \\
\text { shaped } \\
\text { beams }\end{array}$} & \multirow[t]{3}{*}{7} & $\begin{array}{l}\text { Inexperienc } \\
\text { ed operator }\end{array}$ & 6 & $\begin{array}{l}\text { Giving } \\
\text { trainings to } \\
\text { operators }\end{array}$ & 5 & 210 \\
\hline & & & & $\begin{array}{l}\text { Inequal } \\
\text { speed of } \\
\text { operator } \\
\text { and } \\
\text { machine }\end{array}$ & 5 & $\begin{array}{l}\text { Adjusting the } \\
\text { speed } \\
\text { between } \\
\text { operators and } \\
\text { machine }\end{array}$ & 4 & 140 \\
\hline & & & & $\begin{array}{l}\text { Operators } \\
\text { become } \\
\text { bored }\end{array}$ & 6 & $\begin{array}{l}\text { Assigining } \\
\text { different } \\
\text { tasks }\end{array}$ & 5 & 210 \\
\hline
\end{tabular}

\section{Failure Mode and Effect Analysis (FMEA) of folded $L$ shaped beams}

\begin{tabular}{|c|c|c|c|c|c|c|c|c|}
\hline $\begin{array}{l}\text { Process } \\
\text { Funct. }\end{array}$ & $\begin{array}{l}\text { Type } \\
\text { of } \\
\text { Process } \\
\text { Failure } \\
\end{array}$ & $\begin{array}{l}\text { Emerged } \\
\text { Effect }\end{array}$ & $\mathrm{S}$ & $\begin{array}{c}\text { The cause of } \\
\text { failure on } \\
\text { process }\end{array}$ & $\mathrm{O}$ & $\begin{array}{l}\text { Control } \\
\text { to be } \\
\text { done }\end{array}$ & D & RPN \\
\hline \multirow[t]{3}{*}{ Lorry } & \multirow[t]{3}{*}{$\begin{array}{l}\mathrm{L} \\
\text { shaped } \\
\text { beams } \\
\text { folded }\end{array}$} & \multirow{3}{*}{$\begin{array}{l}\text { High } \\
\text { amount } \\
\text { of } \\
\text { disposed } \\
\text { good } \\
\text { quality L } \\
\text { shaped } \\
\text { beams }\end{array}$} & 7 & $\begin{array}{l}\text { Inexperienced } \\
\text { operator }\end{array}$ & 6 & $\begin{array}{l}\text { Giving } \\
\text { trainings to } \\
\text { operators }\end{array}$ & 5 & 245 \\
\hline & & & & $\begin{array}{l}\text { Inequal speed } \\
\text { of operator and } \\
\text { machine }\end{array}$ & 5 & $\begin{array}{l}\text { Adjusting } \\
\text { the speed } \\
\text { between } \\
\text { operators } \\
\text { and } \\
\text { machine }\end{array}$ & 4 & 140 \\
\hline & & & & $\begin{array}{l}\text { Operators } \\
\text { become bored }\end{array}$ & 6 & $\begin{array}{l}\text { Assigining } \\
\text { different } \\
\text { tasks }\end{array}$ & 5 & 210 \\
\hline
\end{tabular}

\section{Conclusions}

1. The dominant failure in lorry production process is the mistake in cutting process when producing the front, back, left and right wall and base, the uncircular form of $\mathrm{L}$ shaped beams in circle making. Torn $\mathrm{L}$ shaped beams in the process of bending internal and external chassis, and folded $\mathrm{L}$ shaped beams in the process of bending the internal and external chassis.

2. In the process of iron plate cutting, failure emergers from operator where the operators being inexperienced with RPN value of 210 .

3. In the process of circle making, failure emerges from untrained operator in circle making with RPN of 210.

4. In the process of bending of the $\mathrm{L}$ shaped beams which the beams are being torn, failure emerges from inexperienced operator and boredom of the operators with RPN value of 210

5. In the process of bending of the $\mathrm{L}$ shaped beams which the beams are being folded, failure emerges from unskilled operator in doing the process with RPN value of 245 .

\section{Acknowledgment}

This research was supported by Research Institute, University of Sumatera Utara. I would like to show my warm thank to Rahmi M. Sari, Khalida Syahputri, M. Anggia Muchtar and Indah Rizkya who supported me at every bit and without whom it was impossible to accomplish the end task. Last, but not least thank to my wife, my son and my daughter, without whom I was nothing; they not only assisted me morally but also extended their support emotionally.

\section{References}

[1] Bahrami, M., 2012, Innovation and Improvements In Project Implementation and Management; Using FMEA Technique, International Conference on Leadership, Technology and Innovation Management, Procedia Social and Behavioral Sciences 41 ( 2012 ) 418 - 425

[2] Besterfield, Dale H. 1994. Quality Control. Edisi Keempat. London: Prentice Hall Intrnational.

[3] Chen, Z., 2014, Risk assessment of an oxygen-enhanced combustor using a structural model based on the FMEA and fuzzy fault tree, Journal of Loss Prevention in the Process Industries, Journal of Loss Prevention in the Process Industries 32 (2014) 349-357

[4] Gülşen Aydın Keskin dan Coşkun Özkan. 2008. An Alternative Evaluation of FMEA: Fuzzy ART Algorithm. Quality And Reliability Engineering International 25 (647-661).

[5] Feili, H.R., 2013, Risk analysis of geothermal power plants using Failure Modes and Effects Analysis (FMEA) technique, Energy Conversion and Management 72 (2013) 69-76.

[6] Meraj, R. 2015, Prediction of subsidence risk by FMEA using artificial neural network and fuzzy inference system, International Journal of Mining Science and Technology 25 (2015) 655-663

[7] Renu, R., 2016, A Knowledge Based FMEA to Support Identification and Management of Vehicle Flexible 
Proc. of Sixth International Conference On Advances in Mechanical, Aeronautical and Production Techniques - MAPT $2016 .$.

Copyright (C Institute of Research Engineers and Doctors. All rights reserved.

ISBN no. 978-1-63248-112-2 doi: 10.15224/ 978-1-63248-112-2-34

Component Issues, 6th CIRP Conference on Assembly Technologies and Systems (CATS), Procedia CIRP 44 ( 2016 ) 157 - 162

[8] Ridwan, Asep, dkk. 2011. Penggunaan Grey FMEA untuk Memperbaiki Mutu Pipa Baja Spiral dalam Penerapan Six Sigma. Cilegon: Jurusan Teknik Industri UNTIRTA

[9] Tambunan, Rudi M. 2008. Standard Operating Procedures (SOP).Jakarta: Maiestas Publishing.

[10]Trafialek, J., 2014, Application of Failure Mode and Effect Analysis (FMEA) for auditof HACCP system, Food Control 44 (2014) 35-44

[11]Umar, Husein.2009. Metode Penelitian untuk Skripsi dan Tesis Bisnis.Jakarta : Rajawali Press.

[12]Wessiani, N. A, Risk analysis of poultry feed production using fuzzy FMEA, Industrial Engineering and Service Science 2015, IESS 2015, Procedia Manufacturing 4 (2015) $270-281$

[13]Wisnu AP. 2008. Quality Control. Jakarta: PT. Gramedia

[14]Yang, Z., 2015, Use of fuzzy risk assessment in FMEA of offshore engineering systems, Ocean Engineering, Ocean Engineering95(2015)195-204

About Author (s):

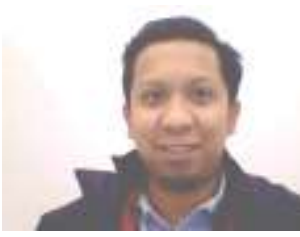

Ikhsan Siregar is a lecturer in Universitas Sumatera Utara (USU), and he has master of engineering of manufacturing. Being a lecturer since 2005 until present and his interest in ergonomics, manufacture, and industrial management. 